\title{
How Urgent are Blood Transfusions Provided in Emergency Service?
}

\author{
Yasemin Özgür, (ㄷ) Seydahmet Akın, (1) Gizem Gecmez, \\ D Nazire Aladağ, (10 Özcan Keskin
}

Department of Internal Medicine, University of Health Sciences, Kartal Dr. Lütfi Kırdar Training and Research Hospital, İstanbul, Turkey

Submitted: 18.05.2018 Accepted: 25.07.2018

Correspondence: Yasemin Özgür SBÜ, Kartal Dr. Lütfü Kırdar Eğitim ve Araştırma Hastanesi, İç Hastalıkları Kliniği, İstanbul, Turkey E-mail: dryaseminozgur@gmail.com

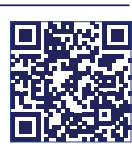

Keywords: Emergency blood transfusion indications; internal medicine: red blood cell; thrombocyte.

\begin{abstract}
Objective: A blood transfusion, defined as a procedure to replace lost blood, is actually a tissue transplantation, performed with consideration given to the impact profile, the potential development of complications, and the risk of anaphylaxis and rejection, which may lead to death. This study is an analysis of emergency blood transfusions in terms of symptoms and indications.
\end{abstract}

Methods: Hospital records of blood transfusions administered in the emergency service were retrospectively reviewed. The patients were categorized into 2 groups: emergency patients and non-emergency patients, based on the presentation.

Results: Over the course of 3 months, 1156 transfusions (2.1 8 per person) were performed in 528 patients $(61.4 \%$ male). It was determined that the most commonly seen patient complaints were weakness (19\%) and melena (14\%), followed by cases in which the patient was asymptomatic, but there was laboratory pathology (12.9\%). In all, $47 \%$ of all cases of blood transfusion were considered urgent.

Conclusion: No correlation was determined between urgency requirement and hemoglobin level. Aside from those administered for active bleeding, most blood transfusions were not performed due to an urgent indication. The establishment of separate, ambulatory parenteral treatment units in could reduce the burden on emergency services to some extent and protect the priority status real emergency patients need.

\section{INTRODUCTION}

The aim of a blood transfusion is to reduce the risks caused by anemia and to provide oxygen to tissues. Though the goal of a blood transfusion is to provide life-saving treatment, there are many studies indicating that the use of a blood transfusion has increased mortality and morbidity. ${ }^{[1]}$ Transfusion-transmitted infections and transfusion-related immunomodulation have led to more discussion of the safety of blood transfusions. ${ }^{[2,3]}$

For many decades, the decision to transfuse red blood cells was based upon the "10/30 rule": a transfusion was used to maintain a blood hemoglobin $(\mathrm{Hb})$ concentration above $10 \mathrm{~g} / \mathrm{dL}(100 \mathrm{~g} / \mathrm{L})$ and a hematocrit above $30 \% .{ }^{[4]} \mathrm{In}$ recent years, a large body of clinical evidence resulted in the publication of many guidelines for blood transfusion in different settings according to the patient's clinical status and oxygen delivery needs. ${ }^{[5-7]}$

The objective of this study was to examine the blood transfusions performed in the internal medicine emergency service unit of a hospital in terms of symptoms and indications, and to investigate whether the factors affecting the decision for an urgent transfusion were the patient's clinical status or the Hb level.

\section{MATERIAL AND METHODS}

\section{Study population}

The records of blood transfusions done in the emergency service unit of the Internal Medicine Clinic at the at University of Health Sciences,Kartal Dr. Lütfi Kırdar 
Training and Research Hospital between September 23 and December 23, 2015 were examined retrospectively. A total of 528 patients were included in the study. Sociodemographic data, diagnosis at the time of arrival, knowledge of known diseases, quantity of blood components requested and transfused from the blood bank, blood group, type of transfusion, and $\mathrm{Hb}$ and platelet $(\mathrm{Plt})$ levels were examined. The hemograms were measured using a Coulter LH780 analyzer (Beckman Coulter, Inc. Inc., Brea, CA, USA). The study protocol was approved by the ethics committee of Kartal Dr. Lutfi Kırdar Training and Research Hospital, in accordance with the Declaration of Helsinki (2018/5/4/128/13).

\section{Definitions}

The blood components transfused were analyzed in 3 sections: erythrocyte products, Plt products, and plasma. Erythrocyte products, that is, erythrocyte suspension (ES) and irradiated erythrocytes (IE); PIt products, namely, pooled Plt (PP), apheresis PIt (AP), and irradiated PIt (IP); and fresh frozen plasma (FFP) were examined separately.

\section{Separation of patients into groups}

The patients were categorized into 2 groups: emergency patients and non-emergency patients, based on condition at presentation. The patients who presented at the hospital due to complaints of intraabdominal acid, diabetic foot complications, nausea, diarrhea, constipation, vomiting, inappetency, weakness, faintness, itching, edema, coughing, falling, dysmenorrhea, dysuria, abdominal pain, widespread pain, icterus, hyperglycemia, hypoglycemia, epigastric pain, scrotal edema, decubitus ulcer, sore throat, petechia, oliguria, fever, and patients who were examined before a biopsy or tooth extraction, surgery, or in the case of a catheter dysfunction, were classified in the non-emergency group.

Patients with active bleeding, such as cases of hematochezia, melena, hematuria, hemoptysis, hematemesis, gingival bleeding, petechia, ecchymosis, tracheostomy bleeding, mucosal bleeding, conjunctival hemorrhage and epistaxis, and patients who presented with complaints of chest pain, dizziness, dyspnea, exertional dyspnea, syncope, tachycardia, impaired consciousness, anuria, hypotension, and seizures were included in the emergency group.

\section{Statistical analyses}

IBM SPSS Statistics for Windows, Version 24.0 (IBM Corp., Armonk, NY, USA) was used to perform the statistical analysis. One-way analysis of variance was applied for multiple intergroup comparisons. After distribution of the variables was controlled using the Kolmogorov-Smirnov test, the independent samples t-test was used in paired comparisons of normally distributed quantitative variables. The
Mann-Whitney $U$ test was used for abnormally distributed groups, and a chi-square test was used to compare qualitative variables. A paired samples t-test was used for the intergroup comparison of continuous parameters, and a post-hoc least significant difference test was used to determine whether there was a statistically significant relationship between the groups. Pearson correlation analysis was performed for normally distributed parameters and Spearman correlation analysis was conducted for abnormally distributed parameters. Receiver-operating characteristic curves were used to determine the optimal urgency cut-off values of $\mathrm{Hb}$. The results were calculated with a $95 \%$ confidence interval with a significance level of $p<0.05$.

\section{RESULTS}

The records of 528 patients (61\% men), received blood transfusion in the emergency service of an internal medicine clinic over the course of 3 months were examined. The average age of the patients, whose ages ranged from 16 to 94 years, was $61 \pm 16$ years; $44 \%$ were geriatric patients. The average $\mathrm{Hb}$ level of the patients was $7.12 \pm 1.17 \mathrm{~g} / \mathrm{dL}$, and the average Plt level was $19 \pm 1210^{9} / \mathrm{L}$ at the time of arrival.

The mean age of the patients was $61.27 \pm 15$ years among the men and $60.89 \pm 18$ years in the women. The average $\mathrm{Hb}$ level was $7.25 \pm \mathrm{l} .7 \mathrm{I} \mathrm{g} / \mathrm{dL}$ in men and $6.93 \pm \mathrm{I} .68 \mathrm{~g} / \mathrm{dL}$ in women, and the average Plt level was $19 \pm 11 \times 10 \% / \mathrm{L}$ in men and $17 \pm 14 \times 10^{9} / \mathrm{L}$ in women. There was no statistically significant difference between the groups in these parameters.

A total of 1505 different blood components were requested for these patients, and 1156 transfusions were performed. That is, $76 \%$ of the requests from the blood bank for blood components were ultimately determined to be necessary and subsequently administered: an average of 2.18 blood components per person.

The blood components transfused were erythrocyte products (70\%), Plt products (10.7\%), and plasma (19.3\%). It was observed that 307 patients received ES, 62 patients received IE, 42 patients received $P P, 8$ patients received $A P$, 7 patients received IP, and 102 patients received FFP. The average $\mathrm{Hb}$ level in the patients who received ES was 6.69 $\mathrm{g} / \mathrm{dL}$. The average Plt level in the patients who received TS was $36 \times 10^{9} / \mathrm{L}$. The blood group distribution of the patients is shown in Figure $I$.

The 3 most common complaints/conditions at the time of arrival were weakness (19\%), melena (14\%), and being asymptomatic (only laboratory pathology) (13\%). Other complaints and symptoms observed are provided in Table I.

At the time of emergency service presentation, the prediagnosis was most often related to the specialties of gas- 


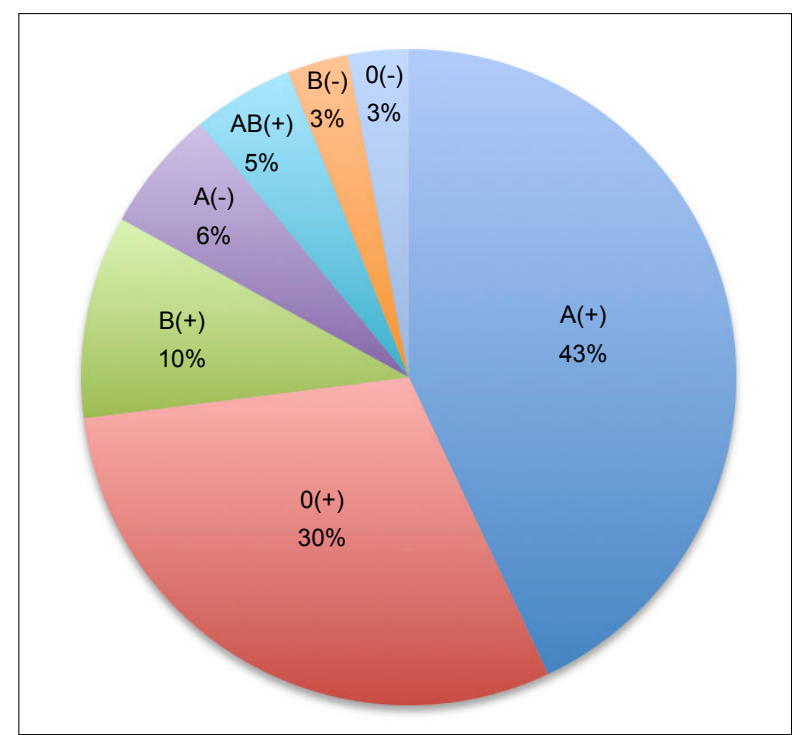

Figure 1. Blood group distribution.

troenterology (34\%), oncology (19\%), and hematological oncology (13\%), as shown in Figure 2 . The only statistically significant difference in terms of urgency was in the gastroenterology patients (Fig. 5).

As in both the clinic and polyclinic setting, it was determined in this emergency service of internal medicine that patients often have a number of chronic diseases, rather than a single isolated disease. When the additional diseases of the patients in our study were examined by branch, excluding acute hemorrhage, it was determined that the

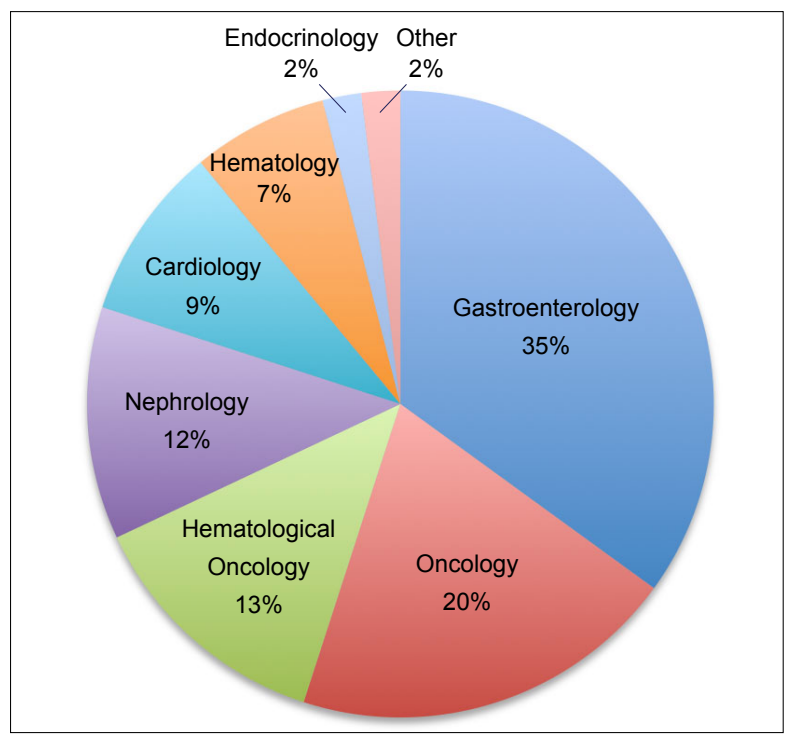

Figure 2. Prediagnosis.

most frequent accompanying diseases were nephrological (21\%), hematological (16\%), oncological (15\%), and cardiological (15\%) disorders (Fig. 3). Examination in more detail revealed that chronic renal disease $(21 \%)$ was most common, followed by hypertension (I7\%) and diabetes mellitus (I3\%) (Table 2).

Excluding 23 patients (4.4\%) referred from another hospital, only $50 \%$ of the patients who received a transfusion of blood components had urgent complaints. The average $\mathrm{Hb}$ level of the 200 patients who received ES replacement and

Table I. Patient condition at hospital admission

\begin{tabular}{|c|c|c|c|c|c|}
\hline Symptom/Condition & Frequency & Percent & Symptom/Condition & Frequency & Percent \\
\hline Weakness & 101 & 19.1 & Anorexia & 6 & I.I \\
\hline Melena & 74 & 14.0 & Paleness & 6 & I.I \\
\hline Asymptomatic & 68 & 12.9 & Diarrhea & 5 & .9 \\
\hline Dyspnea & 56 & 10.6 & Preparation for tooth extraction & 5 & .9 \\
\hline Hematemesis & 46 & 8.7 & Angina & 5 & .9 \\
\hline Another hospital & 18 & 3.4 & Hemoptysis & 4 & .8 \\
\hline Abdominal pain & 18 & 3.4 & Vomiting & 4 & .8 \\
\hline Syncope & 14 & 2.7 & Gingival bleeding & 3 & .6 \\
\hline Epistaxis & 13 & 2.5 & Bleeding & 3 & .6 \\
\hline Hematochezia & 10 & 1.9 & Preoperation & 3 & .6 \\
\hline Widespread pain & 10 & 1.9 & Tachycardia & 2 & .4 \\
\hline Dizziness & 9 & 1.7 & Epigastric pain & 2 & .4 \\
\hline Ununconsciousness & 8 & 1.5 & Catheter dysfunction & 2 & .4 \\
\hline Hematuria & 8 & 1.5 & Petechiae & 2 & .4 \\
\hline Ecchymosis & 7 & 1.3 & Fever & I & .2 \\
\hline Edema & 7 & 1.3 & Sore throat & 1 & .2 \\
\hline Nausea & 6 & I.I & Dysmenorrhea & I & .2 \\
\hline
\end{tabular}




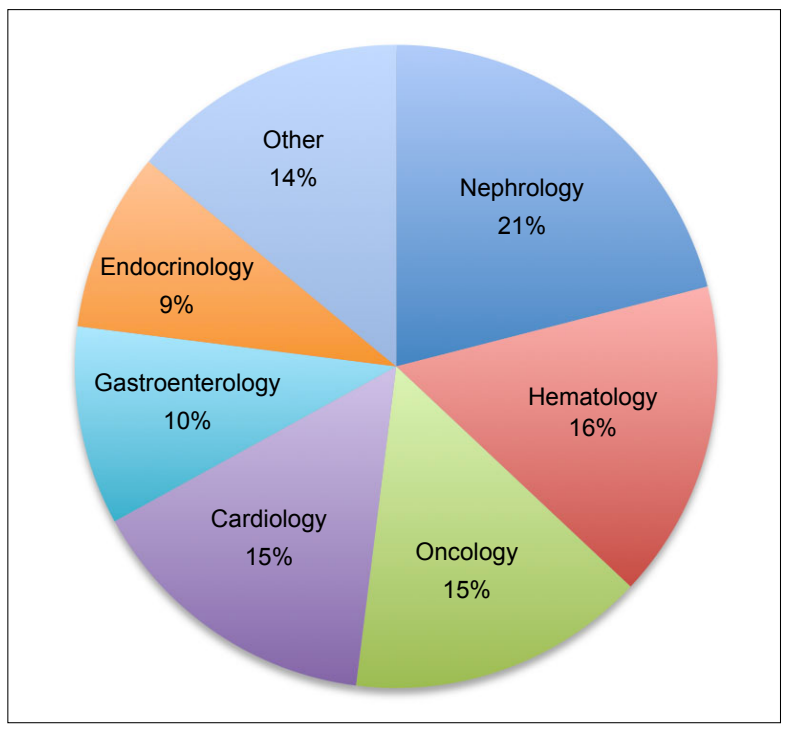

Figure 3. Additional diagnosis.

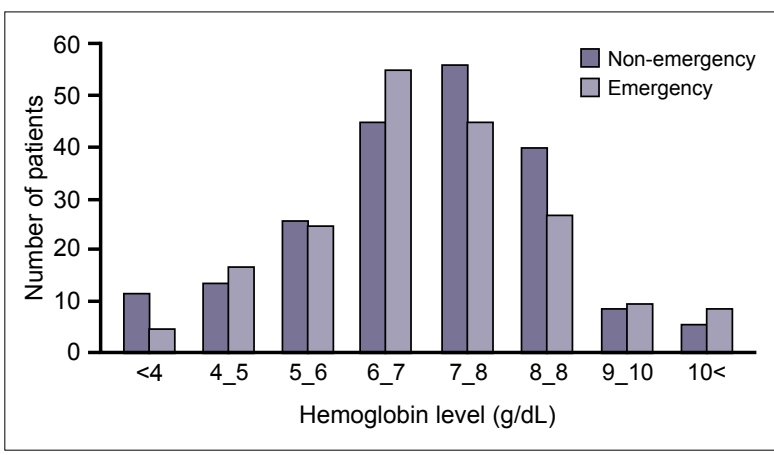

Figure 4. Emergency classification and hemoglobin level.

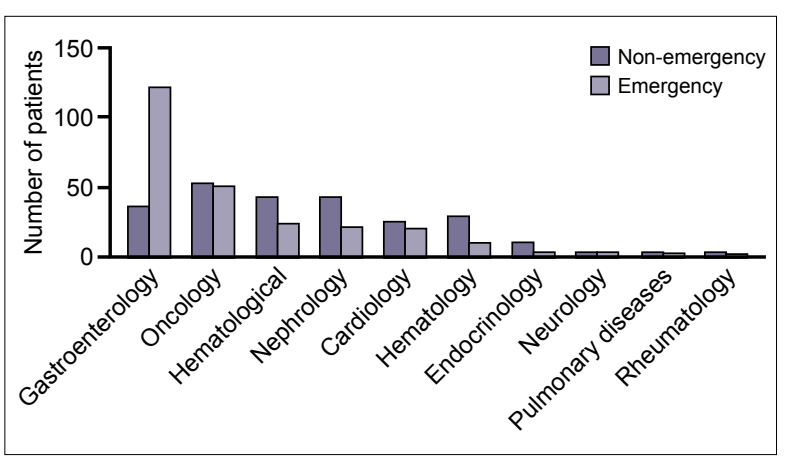

Figure 5. Emergency classification and prediagnosis.

presented at the hospital with non-urgent complaints was $7.03 \pm 1.65 \mathrm{~g} / \mathrm{dL}$; the average of $\mathrm{Hb}$ level of the 185 patients in the emergency group was $7.13 \pm 1.65 \mathrm{~g} / \mathrm{dL}$. Similarly, the average PIt level of the 53 patients in the non-emergency group who received PIt replacement was $18 \times 10^{\circ} / \mathrm{L}$, and the average of the 4 patients in the emergency group was $25 \times 10^{9} / \mathrm{L}$.

Analysis of the $\mathrm{Hb}$ level at the time of arrival indicated that a transfusion of blood components of between 6 and $8 \mathrm{~g} /$ $\mathrm{dL}$ was administered to many patients. However, no cor- relation was observed between $\mathrm{Hb}$ level and the degree of urgency (Fig. 4).

The area under the curve (AUC) was calculated for different threshold levels of $\mathrm{Hb}$ based on the level of urgency. Using Hb cut-off levels of $5 \mathrm{~g} / \mathrm{dL}, 6 \mathrm{~g} / \mathrm{dL}, 7 \mathrm{~g} / \mathrm{dL}, 8 \mathrm{~g} / \mathrm{dL}, 9$ $\mathrm{g} / \mathrm{dL}$, and $10 \mathrm{~g} / \mathrm{dL}$, the AUC was $0.523,0.534,0.486,0.497$, 0.504 , and 0.503 , respectively. No statistical significance was found.

\section{DISCUSSION}

This study examined the complaints, prediagnoses, tests, and examinations performed, as well as any additional diseases diagnosed in patients who received a transfusion of blood components in the emergency service of internal medicine at a hospital with significant experience performing blood transfusions. The factors affecting the decision to provide a blood transfusion were analyzed.

The transfusion of blood components is a deceptively complex form of tissue transplantation in which the $A B O$ $\mathrm{rH}$ compatibility between donor and recipient must be considered and cross-matching is performed to avoid a hemolytic transfusion reaction. All possible risks to the patient should be evaluated before performing a transfusion, as well as the advantages/disadvantages for the patient, the contribution to the present condition of disease that can be expected, the potential to address existing symptoms, and alternative treatment methods.

In our study, the patient's $\mathrm{Hb}$ level at the time of arrival did not have a significant correlation with the urgency of their symptoms. AUC analysis calculated for different $\mathrm{Hb}$ cut-off levels was not statistically significant, and the ideal threshold level for transfusion was determined to be $6 \mathrm{~g} /$ dL (AUC: 0.534 [0.477-0.59I]; $p=0.21 \mathrm{I}$ ).

Therefore, the $\mathrm{Hb}$ level of the patient at the time of arrival should not be a sole determinant for the administration of a blood transfusion. However, a decreased $\mathrm{Hb}$ level in the follow-up period, or more importantly, the development of symptoms of anemia and the impairment of vital findings, are indications for a blood transfusion.

We found that the patients $76 \%$ of the blood components requested for the patients were necessary, while $24 \%$ of the blood products were not ultimately necessary.

A review of the literature confirms that while a blood transfusion is done in the expectation that it will benefit the patient, paradoxically, it may add to the complication rate or ultimately provide no particular advantage. A study examined the $\mathrm{Hb}$ threshold level for $\mathrm{ES}$ replacement in 921 patients with acute gastrointestinal bleeding in terms of efficacy and safety and it was determined that a restrictive strategy $(\mathrm{Hb}<7 \mathrm{~g} / \mathrm{dL})$ resulted in less need for a transfusion (therefore, it is cost-effective), a lower rate of complica- 
Table 2. Additional diseases of patients receiving emergency blood transfusion

\begin{tabular}{|c|c|c|c|}
\hline Diagnosis & Frequency & Diagnosis & Frequency \\
\hline Gastrointestinal bleeding & 122 & Idiopathic thrombotic purpura & 5 \\
\hline Chronic renal failure & 109 & Breast cancer & 5 \\
\hline Hypertension & 92 & Pancreas cancer & 5 \\
\hline Diabetes mellitus & 70 & Rheumatoid arthritis & 5 \\
\hline Coronary artery disease & 63 & Hodgkin's lymphoma & 4 \\
\hline Congestive heart failure & 51 & Chronic lymphocytic leukemia & 4 \\
\hline Gastric carcinoma & 36 & Larynx cancer & 4 \\
\hline Liver cirrhosis & 29 & Myelofibrosis & 4 \\
\hline Coumadin overdose & 27 & Pulmonary hypertension & 4 \\
\hline Lung cancer & 25 & Cervix cancer & 4 \\
\hline Cerebrovascular disease & 25 & Non-Hodgkin's lymphoma & 4 \\
\hline Esophageal varices & 24 & Fistula & 3 \\
\hline Myelodysplastic syndrome & 24 & Familial Mediterranean fever & 3 \\
\hline \multirow[t]{2}{*}{ Chronic obstructive respiratory disease } & 23 & Cholelithiasis & 3 \\
\hline & & Peptic ulcer & 3 \\
\hline Iron deficiency anemia & 23 & Psychosis & 3 \\
\hline Acute myeloid leukemia & 20 & Gall bladder cancer & 3 \\
\hline Urinary bladder cancer & 18 & Ulcerative colitis & 3 \\
\hline Multiple myeloma & 16 & Pulmonary embolism & 3 \\
\hline Valve op. & 15 & Hyperthyroidism & 2 \\
\hline Colon cancer & 14 & Mental retardation & 2 \\
\hline Prostate cancer & 12 & Mesothelioma & 2 \\
\hline Asthma & 11 & Overian cancer & 2 \\
\hline Brain tumor & 11 & Pnomototaks & 2 \\
\hline Hemorrhoid & 10 & Renal cell cancer & 2 \\
\hline Menometrorrhagia & 10 & Pre-operation & 2 \\
\hline Atrial fibrillation & 9 & Acute kidney disease & 1 \\
\hline Gastritis & 9 & Brucellosis & 1 \\
\hline Chronic myeloid leukemia & 8 & Cerebral palsy & 1 \\
\hline Goiter & 7 & Crohn's disease & 1 \\
\hline Amyloidosis & 6 & Febrile neutropenic fever & 1 \\
\hline Benign prostatic hyperplasia & 6 & Kaposi's sarcoma & 1 \\
\hline Deep vein thrombosis & 6 & Osler-Weber-Rendu & 1 \\
\hline Epilepsy & 6 & Osteosarcoma & 1 \\
\hline Hepatitis B (+) & 6 & Paraplegia & 1 \\
\hline BI 2 deficiency & 5 & Parkinson's disease & I \\
\hline Dementia & 5 & Psychosis & 1 \\
\hline Etilizm & 5 & Primary indeterminate cancer & I \\
\hline Factor $V$ Leiden mutation & 5 & Thyroid cancer & 1 \\
\hline Hepatitis C (+) & 5 & Thalassemia & I \\
\hline
\end{tabular}

tions and recurrence of bleeding, and a lower rate of death with uncontrolled bleeding and other reasons when compared with a more liberal strategy $(\mathrm{Hb}<9 \mathrm{~g} / \mathrm{dL}) \cdot{ }^{\left[{ }^{[8]}\right.}$ On the other hand, Carson et al. ${ }^{[9]}$ reported that a liberal transfusion strategy has been associated with a trend of fewer major cardiac events and deaths than a more restrictive 
strategy. Another study showed that a liberal transfusion strategy did not reduce the rate of death or the inability to walk independently at a 60-day follow-up, or reduce in-hospital morbidity in elderly high-risk patients who underwent hip surgery. ${ }^{[10]}$ An analysis of 12 observational studies that included 653 anemic patients with advanced cancer who were given a transfusion found a subjective response rate of $31 \%$ to $70 \%{ }^{\left[{ }^{1 I}\right]}$ Thus, we believe the use of a transfusion in oncology patients should be made on a case-by-case basis.

In fact, other studies have come to the same conclusion, which indicates that rather than the present use of $\mathrm{Hb}$ level, the symptoms of the patient should be a primary consideration in indication for a blood transfusion. In the presence of anemic symptoms, a blood transfusion may be considered regardless of the $\mathrm{Hb}$ value. The symptoms of anemia are usually defined based on a decrease in oxygen delivery to the tissues and an increase in hypovolemia as a result of active bleeding. The symptoms of anemia are indicated as follows:

I. Myocardial ischemia findings or

2. Orthostatic hypotension or

3. Tachycardia unresponsive to fluid replacement or

4. Dyspnea at rest. ${ }^{[12]}$

These symptoms may be significant if they cannot be explained by another condition, such as a massive pulmonary embolism, and furthermore, it should be noted that some patients may not display the typical symptoms of anemia, such as those with diabetic neuropathy.

The impact of a red blood cell transfusion on outcomes in patients with acute coronary syndrome is controversial. A red blood cell transfusion has been associated with an increased risk of short- and long-term mortality, as well as myocardial reinfarction. However, a transfusion appeared to have beneficial or neutral effects on mortality at $\mathrm{Hb}$ levels below $8.0 \mathrm{~g} / \mathrm{dL}$, and harmful effects above $10 \mathrm{~g} / \mathrm{dL} \cdot{ }^{[13,14]}$

The symptoms of chronic anemia are tiredness, weakness, headache, vertigo, angina, exercise intolerance, and dyspnea. The underlying cause is most likely iron deficiency anemia or anemia based on other nutritional deficiencies. Chronic anemia develops slowly as the body adapts via various mechanisms over the long term. Rather than breaking this chain rapidly with the transfusion of blood components, it has been suggested that the deficiency should be corrected in a controlled manner while treating the underlying disease. ${ }^{[15]}$

In our study, unfortunately, the first 3 conditions that led to the administration of a transfusion of blood components were weakness (19\%), melena (14\%), and asymptomatic with laboratory pathology. Unnecessary transfusions may be one reason for density experienced in emergency ser- vices. It should not be forgotten that impatience of both patients and physicians in the treatment of anemia and efforts made to increase the $\mathrm{Hb}$ level immediately may provide disadvantages as well as advantages to the patients. If the bone marrow is healthy, it may be sufficient to wait and provide only any necessary components.

In a study conducted in New York between 2008 and 2010 to reduce the growing use of blood components and the rates of mortality and morbidity, a more limited blood transfusion threshold was implemented based on continuous monitorization of the patient's clinical condition. As a result, the ES transfusion decreased by $30.1 \%$, the Plt transfusion rate decreased by $24.3 \%$, the use of FFP decreased by $41.8 \%$, and the use of cryoprecipitate decreased by $38.7 \%$ in the first year. ${ }^{[16]}$ These results provide us with insight on potential benefits to be obtained by decreasing the rate of unnecessary transfusions and instituting a more controlled approach to both increase patient safety and decrease hospital costs.

Gastroenterology patients, including a relatively large number with gastrointestinal bleeding, were the most frequent emergency service patients to receive a transfusion, followed by oncology patients and hematological oncology patients. Our hospital is a kind of oncology center for the region. Excluding the patients with active gastrointestinal bleeding, it was determined that fewer than $50 \%$ of the patients in these groups required an emergency transfusion of blood components. Ambulatory parenteral treatment units could provide treatment for such patients and decrease the density experienced in emergency services and thereby ensure that patients with a genuine emergency receive priority (Fig. 5).

A limitation of this study is that analysis of vital findings and follow-up could not be performed.

\section{CONCLUSION}

In conclusion, the transfusion of blood components is a very serious intervention and has serious potential complications, though it seems simple and routine. Therefore, the foreseeable risks should be considered when the level of $\mathrm{Hb}$ falls below a certain threshold value, rather than performing a transfusion immediately. The advantages and disadvantages to the patient, the expected contribution to the present condition of disease, the possibility to resolve symptoms, and alternative treatment methods should be carefully analyzed before making a decision to provide a blood transfusion.

The decision to administer a transfusion should be made evaluating not just the $\mathrm{Hb}$ level, but the patient's clinical condition, the underlying reasons for anemia, and important morbidity and mortality considerations. 
Ethics Committee Approval

Approved by the local ethics committee.

Informed Consent

Retrospective study.

Peer-review

Internally peer-reviewed.

Authorship Contributions

Concept: Y.Ö.; Design: Y.Ö., S.A.; Data collection \&/or processing: S.A., G.G.; Analysis and/or interpretation: Y.Ö.; Literature search: N.A.; Writing: Y.Ö., G. G.; Critical review: Ö.K.

Conflict of Interest

None declared.

\section{REFERENCES}

1. Cortés Buelvas A. Anemia and transfusion of red blood cells. Colomb Med (Cali) 2013;44:236-42.

2. Vasudev R, Sawhney V, Dogra M, Raina TR. Transfusion-related adverse reactions: From institutional hemovigilance effort to National Hemovigilance program. Asian J Transfus Sci 2016;10:31-6.

3. Ürkmez S. Blood Transfusions in the Intensive Care Unit [Article in Turkish]. Turkiye Klinikleri J Anest Reanim-Special Topics 2012;5:53-63.

4. Wang JK, Klein HG. Red blood cell transfusion in the treatment and management of anaemia: the search for the elusive transfusion trigger. Vox Sang 2010;98:2-11. [CrossRef]

5. Napolitano LM, Kurek S, Luchette FA, Corwin HL, Barie PS, Tisherman SA, et al; American College of Critical Care Medicine of the Society of Critical Care Medicine; Eastern Association for the Surgery of Trauma Practice Management Workgroup. Clinical practice guideline: red blood cell transfusion in adult trauma and critical care. Crit Care Med 2009;37:3124-57. [CrossRef]
6. Carson JL, Guyatt G, Heddle NM, Grossman BJ, Cohn CS, Fung MK, et al. Clinical Practice Guidelines From the AABB: Red Blood Cell Transfusion Thresholds and Storage. JAMA 2016;316:202535. [CrossRef]

7. Qaseem A, Humphrey LL, Fitterman N, Starkey M, Shekelle P; Clinical Guidelines Committee of the American College of Physicians. Treatment of anemia in patients with heart disease: a clinical practice guideline from the American College of Physicians. Ann Intern Med 2013;159:770-9. [CrossRef]

8. Villanueva C, Colomo A, Bosch A, Concepción M, Hernandez-Gea $\mathrm{V}$, Aracil C, et al. Transfusion strategies for acute upper gastrointestinal bleeding. N Engl J Med 2013;368:11-21. [CrossRef]

9. Carson JL, Brooks MM, Abbott JD, Chaitman B, Kelsey SF, Triulzi DJ, et al. Liberal versus restrictive transfusion thresholds for patients with symptomatic coronary artery disease. Am Heart J 2013;165:964-71.e1. [CrossRef]

10. Carson JL, Terrin ML, Noveck H, Sanders DW, Chaitman BR, Rhoads GG, et al; FOCUS Investigators. Liberal or restrictive transfusion in high-risk patients after hip surgery. $\mathrm{N}$ Engl J Med 2011;365:2453-62. [CrossRef]

11. Preston NJ, Hurlow A, Brine J, Bennett MI. Blood transfusions for anaemia in patients with advanced cancer. Cochrane Database Syst Rev 2012:CD009007.

12. Weiskopf RB, Viele MK, Feiner J, Kelley S, Lieberman J, Noorani M, et al. Human cardiovascular and metabolic response to acute, severe isovolemic anemia. JAMA 1998;279:217-21. [CrossRef]

13. Garfinkle M, Lawler PR, Filion KB, Eisenberg MJ. Red blood cell transfusion and mortality among patients hospitalized for acute coronary syndromes: a systematic review. Int J Cardiol 2013;164:151-7.

14. Allonen J, Nieminen MS, Hiippala S, Sinisalo J. Relation of Use of Red Blood Cell Transfusion After Acute Coronary Syndrome to Long-Term Mortality. Am J Cardiol 2018;121:1496-504. [CrossRef]

15. Lopez A, Cacoub P, Macdougall IC, Peyrin-Biroulet L. Iron deficiency anaemia. Lancet 2016;387:907-16. [CrossRef]

16. Politsmakher A, Doddapaneni V, Seeratan R, Dosik H. Effective reduction of blood product use in a community teaching hospital: when less is more. Am J Med 2013;126:894-902. [CrossRef]

\section{Acil Servisteki Kan Transfüzyonları Ne Kadar Acil?}

Amaç: Kan transfüzyonu eksik olanın yerine konulmasıdır; etki profili, komplikasyon gelişimi, anaflaksi riski, ölüme kadar gidebilen rejeksiyon epizotları ile beraber düşünüldüğünde aslında bir doku transplantasyonudur. Klinik pratiğimizi dahiliye gözüyle semptom ve endikasyon açısından gözden geçirmek amacıyla acil dahiliye servisinde yapılan kan transfüzyonlarını derlemeyi amaçladık.

Gereç ve Yöntem: Hastanemiz acil dahiliye servisinde yapılan kan transfüzyonları geriye dönük olarak hastane bilgi sistemi üzerinden tarand. Hastalar başvuru şikayetlerine göre aciliyet gerektirenler ve aciliyet gerektirmeyenler diye iki gruba kategorize edildi.

Bulgular: Üç ayda dahiliye acil servisinde \%6I.4'ü erkek toplamda 528 hastaya II 56 adet transfüzyon gerçekleştirildi (kişibaşı ortalama 2.18 adet). Başvuru şikayetlerinde ilk üç sırada halsizlik (\%।9), melena (\%|4), yakınmasız (sadece laboratuvar patolojisi) (\%।2.9) yer alıyordu. Aktif kanamayla gelen gastrointestinal sistem kanamaları hariç tutulduğunda ne onkoloji ne hematolojik onkoloji ne de diğer hasta gruplarının temel başvuru şikayetlerine bakıldı̆̆ında aciliyet gerektiren şikayet oranları \%50 dahi değildi. Tüm hastaların \%47'sini ancak acil hastalar oluşturmaktaydı.

Sonuç: İstanbul Anadolu yakasının en kalabalık hastanelerinden biri olan hastanemiz yoğun bir transfüzyon deneyimine sahiptir. Sonuç olarak aciliyet gereksinimi ile hastaların geliş hemoglobin düzeyleri arasında bir korelasyon olmadığı gibi; aktif kanama haricinde acilde yapılan kan ürünleri transfüzyonlarının çoğunun acil endikasyonla yapılmadığı görüldü. Acil servislerin yükünü bir nebze azaltılması ve gerçek acil hastaların önceliğinin korunması adına hastanelerde ayaktan parenteral tedavi ünitelerinin kurulması düşünülebilir.

Anahtar Sözcükler: Acil kan transfüzyonu endikasyonları; eritrosit, iç hastalıkları; trombosit. 